\title{
Development of an Intellectual Property Strategy: Research Notes to Support Department of Defense Programs
}

\section{Charlene Gross}

September 2014

SPECIAL REPORT

CMU/SEI-2014-SR-036

Client Technical Solutions

http://www.sei.cmu.edu 


\section{Report Documentation Page}

Form Approved

OMB No. 0704-0188

Public reporting burden for the collection of information is estimated to average 1 hour per response, including the time for reviewing instructions, searching existing data sources, gathering and maintaining the data needed, and completing and reviewing the collection of information. Send comments regarding this burden estimate or any other aspect of this collection of information,

including suggestions for reducing this burden, to Washington Headquarters Services, Directorate for Information Operations and Reports, 1215 Jefferson Davis Highway, Suite 1204, Arlington

VA 22202-4302. Respondents should be aware that notwithstanding any other provision of law, no person shall be subject to a penalty for failing to comply with a collection of information if it

does not display a currently valid OMB control number.

\begin{tabular}{|c|c|}
\hline $\begin{array}{l}\text { 1. REPORT DATE } \\
\mathbf{0 1} \text { SEP } 2014\end{array}$ & 3. DATES COVERED \\
\hline \multirow{3}{*}{$\begin{array}{l}\text { Development of an Intellectual Property Strategy: Research Notes to } \\
\text { Support Department of Defense Programs }\end{array}$} & 5a. CONTRACT NUMBER \\
\hline & 5b. GRANT NUMBER \\
\hline & 5c. PROGRAM ELEMENT NUMBER \\
\hline \multirow{3}{*}{$\begin{array}{l}\text { 6. AUTHOR(S) } \\
\text { Gross /Charlene }\end{array}$} & 5d. PROJECT NUMBER \\
\hline & 5e. TASK NUMBER \\
\hline & 5f. WORK UNIT NUMBER \\
\hline $\begin{array}{l}\text { 7. PERFORMING ORGANIZATION NAME(S) AND ADDRESS(ES) } \\
\text { Software Engineering Institute Carnegie Mellon University Pittsburgh, } \\
\text { PA } 15213\end{array}$ & $\begin{array}{l}\text { 8. PERFORMING ORGANIZATION } \\
\text { REPORT NUMBER }\end{array}$ \\
\hline \multirow[t]{2}{*}{ 9. SPONSORING/MONITORING AGENCY NAME(S) AND ADDRESS(ES) } & 10. SPONSOR/MONITOR'S ACRONYM(S) \\
\hline & $\begin{array}{l}\text { 11. SPONSOR/MONITOR'S REPORT } \\
\text { NUMBER(S) }\end{array}$ \\
\hline
\end{tabular}

12. DISTRIBUTION/AVAILABILITY STATEMENT

Approved for public release, distribution unlimited.

13. SUPPLEMENTARY NOTES

The original document contains color images.

14. ABSTRACT

15. SUBJECT TERMS

16. SECURITY CLASSIFICATION OF:

a. REPORT

unclassified b. ABSTRACT

unclassified
17. LIMITATION OF ABSTRACT

SAR
18. NUMBER

OF PAGES

52 19a. NAME OF RESPONSIBLE PERSON unclassified 


\section{Copyright 2014 Carnegie Mellon University}

This material is based upon work funded and supported by the Department of Defense under Contract No. FA8721-05-C-0003 with Carnegie Mellon University for the operation of the Software Engineering Institute, a federally funded research and development center.

Any opinions, findings and conclusions or recommendations expressed in this material are those of the author(s) and do not necessarily reflect the views of the United States Department of Defense.

This report was prepared for the

SEI Administrative Agent

AFLCMC/PZM

20 Schilling Circle, Bldg 1305, 3rd floor

Hanscom AFB, MA 01731-2125

NO WARRANTY. THIS CARNEGIE MELLON UNIVERSITY AND SOFTWARE ENGINEERING INSTITUTE MATERIAL IS FURNISHED ON AN “AS-IS” BASIS. CARNEGIE MELLON UNIVERSITY MAKES NO WARRANTIES OF ANY KIND, EITHER EXPRESSED OR IMPLIED, AS TO ANY MATTER INCLUDING, BUT NOT LIMITED TO, WARRANTY OF FITNESS FOR PURPOSE OR MERCHANTABILITY, EXCLUSIVITY, OR RESULTS OBTAINED FROM USE OF THE MATERIAL. CARNEGIE MELLON UNIVERSITY DOES NOT MAKE ANY WARRANTY OF ANY KIND WITH RESPECT TO FREEDOM FROM PATENT, TRADEMARK, OR COPYRIGHT INFRINGEMENT.

This material has been approved for public release and unlimited distribution except as restricted below.

Internal use:* Permission to reproduce this material and to prepare derivative works from this material for internal use is granted, provided the copyright and "No Warranty" statements are included with all reproductions and derivative works.

External use:* This material may be reproduced in its entirety, without modification, and freely distributed in written or electronic form without requesting formal permission. Permission is required for any other external and/or commercial use. Requests for permission should be directed to the Software Engineering Institute at permission@sei.cmu.edu.

* These restrictions do not apply to U.S. government entities.

Carnegie Mellon ${ }^{\circledR}$ is registered in the U.S. Patent and Trademark Office by Carnegie Mellon University.

DM-0001665 


\section{Table of Contents}

Acknowledgments $\quad$ vii

$\begin{array}{ll}\text { Abstract } & \text { ix }\end{array}$

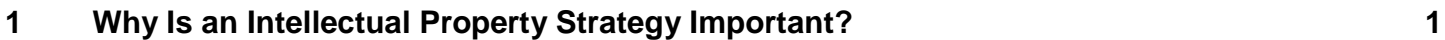

$\begin{array}{lll}1.1 & \text { Intellectual Property as a Strategic Resource } & 1\end{array}$

$\begin{array}{ll}1.2 & \text { Evolution of the IP Strategy }\end{array}$

$\begin{array}{lll}1.3 & \text { Report Objectives and Organization } & 2\end{array}$

2 What is Intellectual Property? 3

2.1 Patent 3

2.1.1 Definition 3

2.1.2 Terms of Patent Ownership 4

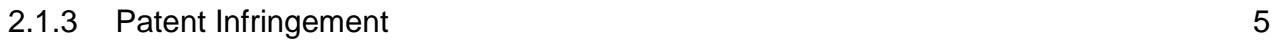

2.2. Copyright $\quad 5$

2.2.1 Definition $\quad 5$

2.2.2 Terms of Copyright Ownership $\quad 5$

$\begin{array}{ll}2.2 .3 & \text { Copyright Infringement }\end{array}$

$\begin{array}{lll}2.3 & \text { Trademark } & 6\end{array}$

2.3.1 Definition $\quad 6$

2.3.2 Terms of Trademark Ownership $\quad 7$

2.3.3 Trademark Infringement $\quad 8$

2.4 Trade Secret $\quad 8$

2.4.1 Definition $\quad 8$

2.4.2 Terms of Trade Secret Ownership $\quad 9$

$\begin{array}{ll}2.4 .3 & \text { Trade Secret Misappropriation }\end{array}$

$3 \quad$ What is the Difference Between IP Ownership and Rights in IP? 11

3.1 Patents and Rights $\quad 11$

$\begin{array}{lll}3.2 & \text { Copyrights and Rights } & 12\end{array}$

$\begin{array}{ll}3.3 & \text { Trademarks and Rights } \\ \end{array}$

$4 \quad$ How Do You Build a Strategy for Rights in IP? $\quad 15$

4.1 Gather Program Information for Operational Context $\quad 15$

4.1.1 Mission Need and Program End Goals 16

4.1.2 Transaction Vehicle and Associated Rights 16

4.1.3 Lifecycle Phase $\quad 19$

4.1.4 Existing Planning Decisions and Program Strategies $\quad 19$

$\begin{array}{lll}4.2 & \text { Identify Deliverables Items and Components } & 20\end{array}$

4.3 Identify IP Protections and Available Rights of Deliverables 22

4.4 Select Specific Rights in IP for Deliverables 23

4.5 Framing a Strategy for Rights in IP $\quad 25$

4.5.1 Needs Assessment Results for Deliverables and Associated Rights in IP 25

4.5.2 Plans for Competitive Acquisition of Deliverables 26

4.5.3 Competitive and Affordable Acquisition and Sustainment Across the Lifecycle 26

4.5.4 IP Planning Elements for DFARS Subpart 207.106 (S-70) 26

4.5.5 Evaluation/Implementation of OSA, Where Cost Effective 27

$5 \quad$ What Are IP Strategy Risks to Consider? $\quad 28$

5.1 Weak or Missing Rationale for the Selected IP Strategy 28

\begin{tabular}{ll}
5.2 & Lack of Planning for Delivery Management \\
\hline
\end{tabular} 
5.3 Lack of Planning for Future Management

5.4 Insufficient History of IP Ownership

5.5 Confusion Over of Rights in IP and Terms

5.6 Misunderstanding of Commercial Software Rights

5.7 Additional Thoughts to Consider 


\section{List of Figures}

Figure 1: $\quad$ Patented Items in an Office Environment [Purvis 2002] 
CMU/SEI-2014-SR-036 | iv 


\section{List of Tables}

Table 1: $\quad$ IP Categories and Owner Rights $\quad 22$

Table 2: $\quad$ Notional Rationales for Parts of an IP Strategy 29 
CMU/SEI-2014-SR-036 | vi 


\section{Acknowledgments}

The author wishes to thank Dr. Michael May (Associate Director for Software and Embedded Systems, Office of the Under Secretary of Defense for Acquisition, Technology, and Logistics), who provided funding for this work in recognition of the importance of intellectual property (IP) to the Department of Defense mission; and Mr. Nickolas Guertin (Director for Transformation, Office of the Deputy Assistant Secretary of the Navy for Research Development Test and Evaluation), who welcomed the author to the Department of Defense IP Strategy Development Guide Team and provided much-needed mentorship on Open Systems Architecture. The author also wishes to acknowledge the insights and advice of the individual team members, whose frank discussions about IP experiences across the services provided significant support in creating this report. A special thank you goes to IP attorneys Jane Barrow (Naval Sea Systems Command, HQ) and George Winborne (U.S. Army Materiel Command, HQ) for sharing both their extensive knowledge and patience. A final bravo goes to Gerald Miller, who wended his way through complicated material and unraveled many ill-conceived sentences. 
CMU/SEI-2014-SR-036 | viii 


\section{Abstract}

Intellectual property (IP) is a critical consideration of most acquisitions that require sophisticated items or components and performance. Preparation of an intellectual property strategy is now a required element in Department of Defense acquisition guidance and major efforts such as Better Buying Power 2.0. The IP Strategy serves as a plan for competitive and affordable acquisition and sustainment of license rights in IP over the entire item or component lifecycle.

This report is intended to help program managers understand categories of IP, various IP challenges, and approaches to assessing the license rights that the program needs for long-term execution and sustainment. Developing a strategy for the entire product lifecycle to obtain specific rights can be a major challenge. The program manager must now prepare the IP Strategy early in the development lifecycle, prior to release of the solicitation, and update it prior to each milestone. 
CMU/SEI-2014-SR-036 | x 


\section{Why Is an Intellectual Property Strategy Important?}

"Program management must identify and manage the full spectrum of IP and related issues (e.g., technical data and computer software deliverables and appropriate rights to use them, and patented technologies embedded in systems) to support an open business model, promote effective competition, and reduce cost, technical, and legal risks to the program" [Interim DoDI 5000.02 2013].

\subsection{Intellectual Property as a Strategic Resource}

Intellectual property (IP) is a critical consideration of most acquisitions that require delivery of technological items, components, or software. Modern military systems are evolving at a rapid pace and need to be quickly revamped. Discovering ways to rapidly field new capabilities with greater military advantage is a primary driver for looking for innovations from a variety of sources. Intellectual property refers to "creations of the mind, such as inventions; literary and artistic works; designs; and symbols, names and images used in commerce” [WIPO 2014]. It is embodied in a form that is shared or can be recreated, emulated, or manufactured.

As the Department of Defense (DoD) acquires and upgrades warfighting systems using transformational product innovations, its highest levels of management appreciate intellectual property as a strategic resource that can generate greater performance for the money. However, a better understanding of how to obtain and manage non-government IP is necessary to improve competition and invigorate a marketplace for businesses that want to innovate and sell to the DoD.

Descriptions of the IP Strategy described in the Interim DoDI 5000.02 instruct program managers and acquisition teams to "assess program needs for, and acquire competitively whenever possible, the deliverables and associated license rights in IP [that are] necessary for competitive and affordable acquisition, and sustainment over the entire product life cycle” [Interim DoDI 5000.02 2013]. With the issuance of this instruction, program managers must now establish and maintain an IP Strategy to encompass all aspects of IP and related issues from the inception of a program and throughout the lifecycle. DoDI 5000.02 requirements for the IP Strategy include development of the strategy itself, a summary for inclusion in the Acquisition Strategy, updates throughout the entire lifecycle, and inclusion in the Lifecycle Sustainment Plan during the operations and support phase [Interim DoDI 5000.02 2013].

\subsection{Evolution of the IP Strategy}

In April 2013, the Office of the Under Secretary of Defense (OUSD) for Acquisition, Logistics, and Technology (AT\&L) released a memorandum titled Implementation Directive for Better Buying Power 2.0-Achieving Efficiency and Productivity in Defense Spending that directed a specific action to “develop IP Strategy Guidance.” OUSD AT\&L released Interim DoDI 5000.02, November 25, 2013, "Operation of the Defense Acquisition System" that provided further explanation of the "IP Strategy." The Interim DoDI 5000.02 states that "program management 
must establish and maintain an IP Strategy to identify and manage the full spectrum of IP and related issues (e.g., Technical Data and Computer Software deliverables, patented technologies, and appropriate license rights) from the inception of a program and throughout the life cycle.”

Past considerations of license rights in IP focused on technical data and computer software. The emphasis was on early phases of the lifecycle, with little consideration of later lifecycle phases such as sustainment. The name of the strategy to address these needs evolved from "data management strategy" in 2007, to "technical data rights strategy" in 2011. The Interim DoDI 5000.02 states that the IP Strategy will describe, at a minimum:

- assessment of program needs for the deliverables and associated license rights

- how program management will acquire competitively whenever possible, the deliverables and associated license rights necessary for competitive and affordable acquisition and sustainment over the entire product lifecycle

In addition to developing the strategy, the program manager must also include a summary of the IP Strategy in the program's Acquisition Strategy; and it must

- be completed prior to the solicitation

- reflect all functional disciplines from inception through sustainment and disposal

- $\quad$ address all phases of a program lifecycle

- $\quad$ be updated throughout the lifecycle

\subsection{Report Objectives and Organization}

The objective of this report is to gather and clarify much-needed information about intellectual property into a readable and consumable source that supports program managers and their teams. The author gathered this information while serving as a member of the DoD IP Strategy Development Guide Team. It is not a comprehensive treatment of all legal and contractual information related to rights in IP, but it does provide pointers to sources of information and encourages further research when creating, monitoring, or revising a program's IP Strategy.

This report introduces information on intellectual property categories and associated rights to educate program managers on the role of program execution. The content also explains implications of transaction types, methods for gathering information to formulate a strategy for rights in IP, and how to assess program needs for license rights in IP. With this information, the program manager can prepare an informed IP Strategy document, and effectively execute the documented strategy. 


\section{What is Intellectual Property?}

The Congress shall have Power ... To promote the Progress of Science and useful Arts, by securing for limited Times to Authors and Inventors the exclusive Right to their respective Writings and Discoveries. [U.S. Constitution Art. I, § 8, cl. 8.]

Many people who are responsible for programs that involve rights in IP do not have a strong foundation in the nature and role of IP. They may believe that the IP is the actual product that they acquire, or think that IP means "just software.” They may assume that they have already paid for both the IP and the product, so should be able to do whatever they want with it. Each of these statements is incorrect; for these reasons, this report starts with a discussion about what IP is and what it is not.

IP broadly refers to intangible "creations of the mind"-inventions, literary and artistic works, unique business names and symbols, and internal secret information. Items and components that embody intellectual property are most likely a tangible item, e.g., a tank, a missile, a radar system, or an IT system. The protections granted to owners of intellectual property embodied in the item or component could be a patent, a copyright, a trademark, or a trade secret.

Federal IP law originated in the United States Constitution, federal statutes, federal regulations, and the common law of court opinions issued by federal judges. The Constitution authorized Congress to "promote the progress of science and useful arts by securing for limited times to authors and inventors the exclusive right to their respective writings and discoveries [U.S.

Constitution Art. I, § 8, cl. 8.].

Congress has passed bills on copyrights (17 U.S.C.), patents (35 U.S.C.), and trademarks (15 U.S.C.) The following discussion provides definitions, terms of ownership, and conditions of use.

\section{$2.1 \quad$ Patent}

\subsubsection{Definition}

A patent is a category of intellectual property rights that the government of the United States of America grants to an inventor for a limited time in exchange for public disclosure of the invention when the patent is granted [USPTO 2014]. 35 U.S.C. 101 states that "whoever invents or discovers any new and useful process, machine, manufacture, or composition of matter, or any new and useful improvement thereof, may obtain a patent therefor, subject to the conditions and requirements of this title.”

People who are not attorneys may not have sufficient understanding of how patents can become problematic without adequate attention. In these times of constant technological innovation, the DoD acquires many patented items and also owns many patents. Figure 1 is an example of the ubiquitous nature of patented items in the everyday work environment. 


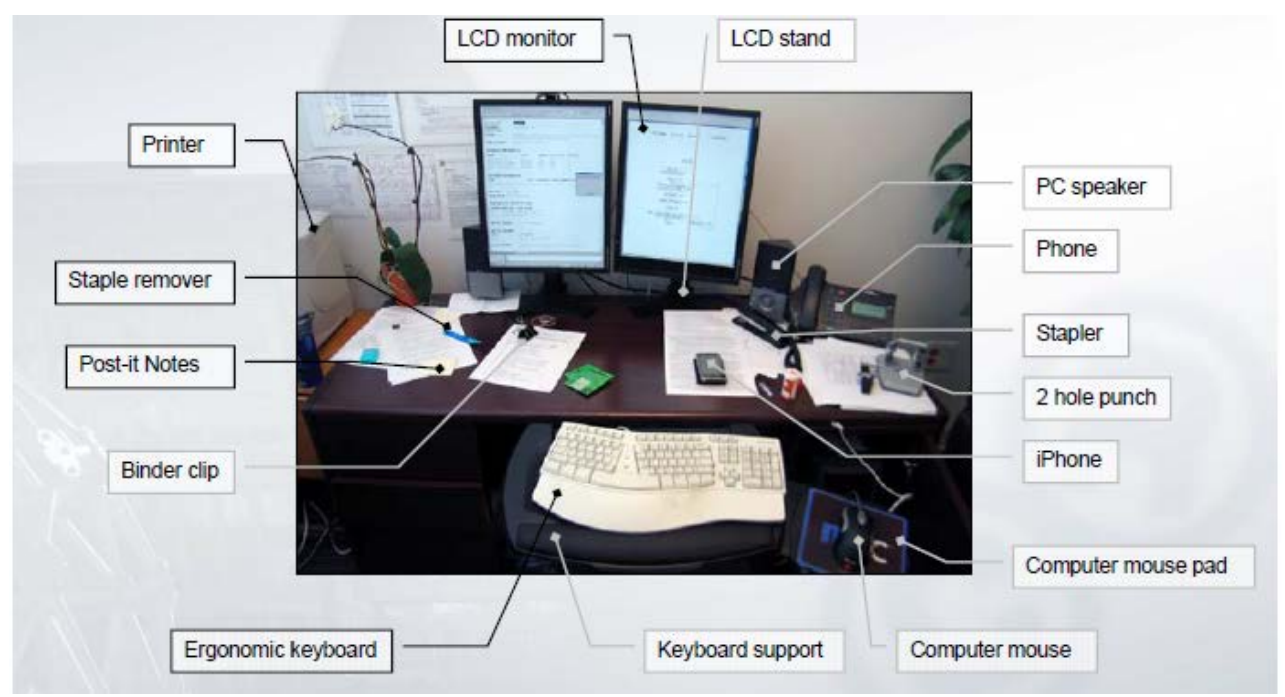

Figure 1: Patented Items in an Office Environment [Purvis 2002]

Three types of patents are:

- utility patents: granted to anyone who invents or discovers any new and useful process, machine, article of manufacture, or composition of matter, or any new and useful improvement thereof

- $\quad$ design patents: granted to anyone who invents a new, original, and ornamental design for an article of manufacture

- $\quad$ plant patents: granted to anyone who invents or discovers and asexually reproduces any distinct and new variety of plant [USPTO 2011]

\subsubsection{Terms of Patent Ownership}

An inventor must apply for a patent, and can be refused if the invention does not meet the three criteria of patentability—new, nonobvious, and useful. With approval of the patent application by the United States Patent and Trademark Office, the patent owner receives the right to exclude others from making, using, offering for sale, or selling the invention throughout the United States or importing the invention into the United States. Federal acquisition regulations typically encourage innovation by allowing inventors (or their employer under the "work for hire" doctrine or agreement) to retain ownership of patents, even when totally funded by government contracts.

The government may also own patents when the inventor is a federal employee. Under 37 CFR $\S$ 501.6 - Criteria for the Determination of Rights in and to Inventions, the government obtains all rights to any invention made by its employee if any one of the following conditions applies:

- $\quad$ The invention is made during working hours.

- The invention is made using government facilities, equipment, etc., or is made with the help of another government employee who is on official duty.

- The invention relates to the official duties of the inventor. 
Under terms of the order, the government does not have to take title if it would be inequitable, such as minimal use of government time or materials.

\subsubsection{Patent Infringement}

Patent infringement is the act of making, using, selling, or offering to sell a patented invention, or importing into the United States a product covered by a claim of a patent without the permission of the patent owner [USPTO 2014]. 28 U.S.C. § 1498(a) governs patent infringement cases brought against the government. The court cannot stop (enjoin) the government from using the patented item. The only remedy for the owner is action against the United States in the United States Court of Federal Claims for the recovery of his reasonable and entire compensation for use and manufacture. However, that compensation and the time spent to mount a defense in court can be substantial. In the case of infringement by a contractor working on a government project, the patent owner can still sue the government when the proper Federal Acquisition Regulation (FAR) clauses are in the contract.

When FAR 52.227-3 is in the contract for the purchase of commercial items, the contractor is required to reimburse the U.S. government for liabilities resulting from actions under 28 U.S.C. $\S$ 1498 [Kaprove 2012]. An Administrative Claim can be brought against a government agency for patent infringement pursuant to the Defense Federal Acquisition Regulation Supplement (DFARS) 227.70, which goes directly to the agency for disposition.

\subsection{Copyright}

\subsubsection{Definition}

Copyright is a form of protection for authors of "original works of authorship." Under Title 17 of the United States Code subject matter protected by copyright is "original works of authorship fixed in any tangible medium of expression" so that it is perceptible either directly or with the aid of a machine or device. Under the Library of Congress, the United States Copyright Office is responsible for copyright protection and issuance. Works could include literary, dramatic, musical, and artistic works, such as poetry, novels, movies, songs, computer software, drawings, and architecture.

A copyright owner has the exclusive right to reproduce, distribute, perform, and display the work in question, as well as the right to prepare derivative works. Length of protection is complicated due to changes in the law, but currently is 70 years after the death of author. If there is corporate authorship of the work, the protection is for 95 years from publication or 120 years from creation, whichever expires first. The copyright "protects the form of expression rather than the subject matter of the writing. For example, a description of a machine could be copyrighted, but this would only prevent others from copying the description. It would not prevent others from writing a description of their own or from making and using the machine” [USPTO 2011].

\subsubsection{Terms of Copyright Ownership}

An author does not have to apply for the copyright to obtain protection for his/her original work of authorship. When the work is fixed in a tangible expression, the author of a copyrightable work 
automatically owns a copyright to it. With U.S. adherence to the Berne Convention, effective March 1, 1989, the material work can carry a copyright notice (C), whether it is registered with the Copyright Office or not.

Even though copyright protection is not dependent on registration, the U.S. Copyright Office lists the following advantages of registration:

- a public record of the copyright claim

- $\quad$ evidence in court of copyright validity

- $\quad$ ability to file an infringement suit (registration is necessary for works of U.S. origin)

- collection of statutory damages and attorney's fees under certain conditions

- $\quad$ registration with the U.S. customs service to protect against importation of infringing copies

Under U.S. copyright law, an employer owns the copyright on a work prepared by an employee as part of "work for hire." A "work made for hire" is a work prepared by an employee within the scope of his or her job. Since contractors, grantees and certain individuals who work under contracts with the DoD are not considered government employees for purposes of copyright, copyrights for works created under these government contracts would also be the property of the contractor.

A "work of the United States Government" is a work prepared by an officer or employee of the United States government as part of that person's official duties. Under 17 U.S.C. § 105, neither a government employee nor the government itself can hold copyrights for works created as part of direct government employment. However, the United States government can receive and hold copyrights transferred to it by assignment, bequest, or other means.

While not protected by copyrights, U.S. government works and works protected by copyright, e.g., contractor works prepared for the U.S. government, can be subjected to other legal limitations related to national security, export control, controlled unclassified information (CUI), personally identifiable information (PII), or other reasons that govern their use.

\subsubsection{Copyright Infringement}

Copyright infringement occurs when someone reproduces, distributes, performs, publicly displays, or makes a copyrighted work into a derivative work without the copyright owner's permission. In order to sue the U.S. government for infringement, 28 U.S.C. § 1498 (b) provides, in part, that "the exclusive action which may be brought for such infringement shall be an action by the copyright owner against the United States in the Court of Federal Claims [not a district court] for the recovery of his/her reasonable and entire compensation as damages for such infringement, including the minimum statutory damages.”

\subsection{Trademark}

\subsubsection{Definition}

A trademark or service mark includes any word, name, symbol, device, or any combination, used or intended to be used to identify and distinguish the goods/services of one seller or provider from 
those of others, and to indicate the source of the goods/services [USPTO 2014]. 15 USC § 1127 states that a trademark includes any device, brand, label, name, signature, word, letter, numerical, shape of goods, packaging, color or combination of colors, smell, sound, movement, or any combination thereof, so long as it identifies the source of goods and services and distinguishes them from the goods and services of others. ${ }^{1}$

Registration of a trademark can be at the federal level, which would protect it across the U.S.; or at the state level, which protects in only in the state(s) where registered. Common law rights in a mark are rights that are developed through use and are not governed by statute but are protectable based on case law. "The USPTO can refuse registration of a proposed mark for many other reasons, including but not limited to the mark being: a surname; geographically descriptive of the origin of the goods/services; disparaging or offensive; a foreign term that translates to a descriptive or generic term; an individual's name or likeness; the title of a single book and/or movie; and matter that is used in a purely ornamental manner” [USPTO Trademark 2014].

An ${ }^{\circledR}$ symbol means that the mark has been registered with the federal government and is subject to legal action if used without license or permission. Trademark renewals are required every 10 years. Owners of trademarks can license their use by others. A ${ }^{\mathrm{TM}}$ symbol indicates an unregistered federal trademark (used prior to receiving the federal trademark registration), a registered state mark or a common law mark. An ${ }^{\text {SM }}$ symbol is a service mark. It is a trademark used in the United States and several other countries to identify a service rather than a product. When a service mark is federally registered, the standard registration symbol ${ }^{\circledR}$ is used (the same symbol is used to mark registered trademarks).

\subsubsection{Terms of Trademark Ownership}

The owner of a trademark or service mark must file an application with the U.S. Patent and Trademark Office (USPTO) to receive federal registration and nationwide rights. Individual states also offer to register trademarks, but that protection granted is limited to that state. Federal registration establishes:

- a legal presumption of ownership of the mark, as listed in the USPTO database

- a legal presumption of the exclusive right to use the mark nationwide

- listing in the USPTO database as the trademark owner

- ability to record the trademark with U.S. Customs and Border Protection to prevent importation of infringing or counterfeit foreign goods

- the right to bring legal action concerning the registered mark in federal court

- a basis for applying for a trademark registration in many foreign countries [USPTO 2009]

The government can also own trademarks. 10 U.S.C. § 2260 authorizes the Secretary of Defense to register qualifying trademarks relating to "military designations and likenesses of military weapons systems," and to license these trademarks upon request. Chapter 31 of the DoD Financial Management Regulations defines the necessary procedures for dealing with any licensing fees

$1 \quad$ http://www.bitlaw.com/trademark/infringe.html 
generated. An example of a federally registered trademark by the U.S. Marine Corps is "A Few Good Men,” which is licensed and cannot be used without permission.

\subsubsection{Trademark Infringement}

Infringement of a trademark occurs when use of the mark causes confusion about the source or origin of goods. A plaintiff in a trademark case has the burden of proving that the defendant's use of a mark has created the "likelihood of confusion" about the origin of the defendant's goods or services. "Use," "in commerce," and "likelihood of confusion" are three distinct elements necessary to establish a trademark infringement claim [LII 2014]. For example, the public might believe that the defendant's products are the same as that of the plaintiff, or that the defendant is somehow associated, affiliated, connected, approved, authorized, or sponsored by the plaintiff.. The U.S. government can be stopped/enjoined from use of a mark if it was found by the court to have infringed someone else's mark

A concern of trademark owners is the evolution of their mark into a "generic term." Trademark history describes several distinctive marks that have become generic over time. Aspirin, cellophane, margarine, videotape, escalator, and linoleum all began as fanciful or arbitrary marks that now represent an entire category of product.

\subsection{Trade Secret}

\subsubsection{Definition}

18 U.S.C. Part 1, Chapter 90 § 1839 defines “trade secret” as "all forms and types of financial, business, scientific, technical, economic, or engineering information, including patterns, plans, compilations, program devices, formulas, designs, prototypes, methods, techniques, processes, procedures, programs, or codes, whether tangible or intangible, and whether or how stored, compiled, or memorialized physically, electronically, graphically, photographically, or in writing if-

- the owner thereof has taken reasonable measures to keep such information secret; and

- the information derives independent economic value, actual or potential, from not being generally known to, and not being readily ascertainable through proper means by, the public.”

A version of the Uniform Trade Secrets Act (UTSA) has been passed by most states to provide a consistent legal framework for trade secret protection across the states. Section 757 of the UTSA lists six factors to be considered in determining whether information constitutes a trade secret:

- $\quad$ extent to which the information is known outside the claimant's business

- $\quad$ extent to which it is known by employees and others involved in the business

- extent of measures taken by the claimant to guard the secrecy of the information

- $\quad$ value of the information to the business and its competitors

- amount of effort or money expended by the business in developing the information

- $\quad$ ease or difficulty with which the information could be properly acquired or duplicated by others [IT Law 2014] 
Reasonable measures for ensuring secrecy include building access controls, escorting visitors, marking sensitive documents, nondisclosure agreements, and shredding material when no longer needed [USDA 2014].

\subsubsection{Terms of Trade Secret Ownership}

A trade secret owner is the person or entity "in whom or in which rightful legal or equitable title to, or license in, the trade secret is reposed,” according to 18 U.S.C. Part $90 \S 1839$. More than one person can hold trade secret protection with respect to the same information.

There is no registration issued by the government for a trade secret. Unlike patents, trade secrets can be licensed forever. Karl Jorda provides questions that trade secret recipients should answer for their own situation when obtaining a license to a trade secret:

- What restrictions should they accept on use of the information if they want to license and use it?

- What restrictions should they accept on the future use of the information, if they do not want to license it?

- What if the information is already in the public domain?

- What if it turns out that they are already in possession of the information, or an important part of it?

- How much should they pay for a look into the black box [Jorda 2007]?

\subsubsection{Trade Secret Misappropriation}

Theft or misappropriation of trade secrets is a federal criminal offense under 18 U.S.C. Part $90 \S$ 1831-1839. Both theft of a trade secret to benefit a foreign entity and commercial theft of trade secrets are criminal acts. This section of the U.S. Code also describes terms for fines and imprisonment for trade secret misappropriation.

There is no general definition for "proprietary information" in the U.S. legal code; although some sources suggest that it is the same as a "trade secret." The Federal Acquisition Regulation (FAR) (27.402 Policy) does state that "contractors may have a legitimate proprietary interest (e.g., a property right or other valid economic interest) in data resulting from private investment. Protection of such data from unauthorized use and disclosure is necessary in order to prevent the compromise of such property right or economic interests, avoid jeopardizing the contractor's commercial position, and preclude impairment of the Government's ability to obtain access to or use of such data.”

The trade secret owner can prevent the following groups of people from copying, using, or benefiting from its trade secrets or disclosing them to others without permission:

1. people who are automatically bound by a duty of confidentiality not to disclose or use trade secret information

2. people who acquire a trade secret through improper means

3. people who knowingly obtain trade secrets from people who have no right to disclose them 
4. people who learn about a trade secret by accident or mistake, but knew that the information was a protected trade secret

5. people who sign nondisclosure agreements [Experts123 2014]

A written agreement is the safest way to preserve secrecy and should have provisions that define the area of technology with precision and establish a confidential legal relationship between the parties. It should also furnish proprietary information for a specific purpose only, oblige the recipient to hold information in confidence, and spell out exceptions to secrecy obligations [Jorda 2007].

Government employees are not authorized to sign a nondisclosure agreement. In fact, there is criminal liability if a government employee were to release or disclose a contractor's trade secret to a third party under 18 U.S.C, § 1905. DFARS 252.227-7025 provides a process for contractor's technical data and computer software containing trade secrets to be provided to a third party by a government employee.

\subsection{Public Domain-NOT Intellectual Property}

Public domain refers to works that are not protected by intellectual property law and are publicly available. No permission is needed to copy or use public domain works. Public domain works can serve as the foundation for new creative works and can be quoted extensively.

The Copyright Office of the Library of Congress offers examples of what might cause the work to be in the public domain in the United States, e.g. any work published in the U.S. prior to 1923. They include "lack of proper notice, failure to renew, failure to comply with manufacturing requirements, or being a sound recording fixed prior to U.S. protection.” If the work comes from outside of the U.S., and the source nation and the United States did not then have a treaty relationship, the work would also be ineligible for a copyright [Copyright Office 2005]. While a U.S. government work is not protected by copyright law in the U.S, it may still be protected in certain foreign countries. 


\section{What is the Difference Between IP Ownership and Rights in IP?}

As previously stated, intellectual property refers to creations of the mind, which are inventions, literary and artistic works, and symbols, names, and images used in commerce. When the government contracts for and receives a product that is protected by intellectual property law, it owns the tangible item (e.g., software, airplane wing, etc.). However, it does not receive ownership of the intellectual property. There is a transfer of the material object, but "transfer of ownership of any material object, including the copy or phonorecord in which the work is first fixed, does not of itself convey any rights in the copyrighted work embodied in the object” [17 U.S.C. § 202].

When the DoD buys a protected work, it owns the delivered item and must pay for certain license rights, such as use, reproduction, display, performance, modification, disclosure, and release of the work. Licenses define the rights and terms between the parties to the agreement. A widely used definition of "license" is "the permission granted by competent authority to exercise a certain privilege that, without such authorization, would constitute an illegal act.” Royalties are payments made by the licensee to the licensor in exchange for rights owned by the licensor.

\subsection{Patents and Rights}

Any person is ordinarily free to make, use, or sell whatever is owned, and a grant from the government is not necessary. A patent is a property right granted for a limited time by the U.S. government to an inventor in exchange for public disclosure of the invention when the patent is granted. The inventor rights are to:

1. exclude others from making the invention

2. exclude others from using the invention

3. exclude others from offering for sale, or selling the invention throughout the United States or importing the invention into the United States [USPTO 2014]

A license agreement with the IP owner allows the purchaser to make, use, sell, and/or import a patented invention without charges of infringement. The patent holder retains IP ownership and earns royalty payments under a license agreement.

When the DoD procures an item that is subject to patent protection, the license rights include a royalty fee that the government pays for use of the item. When the government pays for research and development, it most likely has a license in any patent that results. If an agency is planning on signing a license agreement that includes a royalty based on a patent, it should check to see if another agency already has a license and/or owns the patent. In that case, a royalty may not be required. If the government were to own a patent in an item, the government would still be the patent owner and should not pay a royalty. 


\subsection{Copyrights and Rights}

Copyright protection is available for both published and unpublished works. "Section 106 of the 1976 Copyright Act generally gives the copyright owner the exclusive right to do the following:

- reproduce the work in copies or phonorecords

- prepare derivative works based upon the work

- distribute copies or phonorecords of the work to the public by sale or other transfer of ownership, or by rental, lease, or lending

- $\quad$ perform the work publicly, in the case of literary, musical, dramatic, and choreographic works, pantomimes, motion pictures, and other audiovisual works

- display the work publicly, in the case of literary, musical, dramatic, and choreographic works, pantomimes, and pictorial, graphic, or sculptural works, including the individual images of a motion picture or other audiovisual work

- perform the work publicly (in the case of sound recordings) by means of a digital audio transmission” [Copyright Office 2012].

The scope of the DoD's licensing rights in non-federal works is governed by the DFARS. According to information from CENDI (Commerce, Energy, NASA, Defense Information Managers Group), the government's license rights that are granted by the IP owner generally depend upon the source of the funding (i.e., government, mixed or private), the nature of the data (commercial or noncommercial), and any negotiated terms of the contract.

Questions about copyright status of joint works authored by a government employee and nonfederal author(s) as a team can be tricky because the government and non-federal contributions may be impossible to separate. Whether the U.S. government can be a joint author with a nonfederal author requires consultation with legal counsel since it is not directly addressed by the law. ${ }^{2}$

\subsection{Trademarks and Rights}

A trademark is a word, phrase, symbol or design, or a combination thereof, that identifies and distinguishes the source of the goods of one party from those of others. It typically protects brand names and logos used on goods and services [USPTO Trademark 2014].

"A trademark license is an agreement between a trademark owner (the 'licensor') and another entity (the 'licensee') in which the licensor permits the licensee to use its trademark in commerce. Usually, a trademark license is a written contract specifying its term, conditions for use, renewal and termination, and royalty" [INTA 2014]. There is usually an explicit royalty amount stated in the license.

2 CENDI Copyright and Intellectual Property Working Group. Permissions-Government Prepared and NonFederal Authored Works: Best Practices for U.S. Government Agencies. Part 1. CENDI Secretariat. Oak Ridge, TN. 2014 (publication pending). 
According to the International Trademark Association (INTA), "the trademark owner may grant an exclusive license to a single licensee or a non-exclusive license to more than one licensee. In a non-exclusive licensing arrangement, the licensor/owner retains rights to use the trademark itself, to license it to others, or both.” The United States has no legal requirement to record trademark licenses with the Patent and Trademark Office, but recordation would notify the public of the existence of the license agreement. Other countries do require that licenses be recorded to be effective against third parties.

The trademark owner is responsible for the health of the mark, which should not be diluted, made generic, or used by another company. Quality control is needed because a trademark and the trademark owner's reputation are linked in the minds of the public. Dilution is when a company in a different industry uses a mark that is so similar to the registered trademark that it confuses the customer. "Whether infringing use copies a trademark, dilutes it, or attempts to make it generic, enforcing a trademark is the responsibility of the person who holds it, and doing so may require legal action against the infringing party” [Holloway 2014].

\subsection{Trade Secrets and Rights}

Trade secrets (which are kept confidential) and patents (which require full disclosure to be granted) are not incompatible. When the DoD obtains the technical data relating to an item it purchases, the technical data will most likely contain one or more trade secrets. The DoD's license rights in the trade secrets are defined in the DFARS and the specific license rights found in the contract. These license rights could be limited to use of the technical data only within the government or could extend to disclosure or release of the technical data containing trade secrets outside the government. These limitations depend on the data rights (license rights) that the government obtained in the contract However, protection for trade secrets, unlike patents, lasts as long as the secret is confidential or until it is publicly disclosed. The licensee can be obligated to continue paying royalties for the trade secrets license even if the information (subject to the trade secret license) has entered the public domain.

In the prominent Listerine formula case, the inventor of the Listerine formula, Dr. J. J. Lawrence, accepted an agreement with J. W. Lambert to receive \$20 for every gross of Listerine sold by Lambert, his heirs, executors, or assigns. Lambert assigned his Listerine rights to the Lambert Pharmaceutical Company, which became Warner-Lambert Pharmaceutical Company. After 75 years of payments based on the amount sold, Warner-Lambert sued to end the royalty payments in 1956 because the Listerine formula was no longer a trade secret. The court upheld the licensing agreement since it was based on paying licensing fees and not the fact that the Listerine formula was a trade secret [Warner-Lambert 1960].

A trade secret owner's rights are to:

1. copy the trade secret

2. use the trade secret

3. benefit from the trade secret

4. disclose the trade secret 
Contracts will have a firm agreement regarding disclosure, if any, of contractor trade secrets, technical designs or concepts, and specific data, or software, of a proprietary nature.

Under trade secret law, people cannot be stopped from using the trade secret information that they discover independently without using illegal means or violating agreements or state law; or if they make the discovery by reverse engineering. The owner can prevent the following groups of people from copying, using, or benefiting from its trade secrets or disclosing them to others without permission:

1. people who are automatically bound by a duty of confidentiality not to disclose or use trade secret information

2. people who acquire a trade secret through improper means

3. people who knowingly obtain trade secrets from people who have no right to disclose them

4. people who learn about a trade secret by accident or mistake, but knew that the information was a protected trade secret

5. people who sign nondisclosure agreements [Experts123 2014]

Since trade secrets are by definition not disclosed to the world at large, owners of trade secrets seek to protect trade secret information from competitors by instituting special procedures for handling it, as well as technological and legal security measures. Legal protections include nondisclosure agreements (NDA) and noncompete clauses. A nondisclosure agreement, also called a confidentiality disclosure agreement (CDA), confidentiality agreement, or secrecy agreement, is a legal contract between at least two parties which outlines confidential materials the parties wish to share with one another for certain purposes, but wish to restrict from generalized use.

\subsection{Hybrid Licenses}

The hybrid license is frequently used. Two or more types of intellectual property are covered by a single license. Opinions vary on whether this is a best practice or a risk. For example, a hybrid license could cover both a patented item and also a trade secret in the same license. One wellknown concern about this type of license is that there could be conflicts between time limits of different IP categories. In the case of a hybrid patent-trade secret license, all obligations to pay end when patent rights expire or are terminated. Since trade secret protection does not expire as long as it meets the definition of a trade secret, extending payments for trade secrets after the patent rights terminate requires specific wording in the license or contract [Cavicchi 2007]. 


\section{How Do You Build a Strategy for Rights in IP?}

Developing a strategy for rights in IP is a daunting exercise of determining needs for rights in IP across the whole product lifecycle for all end items - and doing it prior to release of the solicitation. The program manager and his or her acquisition team lead the development of the IP Strategy that will be proposed.

A general approach to developing a strategy is to understand the mission and end goals or desired outcomes, review the operational context or situation, identify options, and select the best options based on evaluation that will satisfy the goals. The outcome of this process is the strategy to support needs and associated capabilities.

In the case of a strategy for rights in IP, the process does not begin by picking a strategy and then justifying it. Rather, it begins by gaining knowledge about the program. It focuses on

- understanding the operational context

- identifying contract deliverable and types of IP protections associated with each deliverable

- $\quad$ selecting rights that support needed capabilities

- gathering together the information to develop a strategy for rights in IP to meet the expectations of the Interim DoDI 5000.02

Development of a strategy for rights in IP begins early in the development lifecycle, continues with updates prior to each lifecycle phase, and accompanies each RFP that potential offerors receive. The Interim DoDI 5000.02 provides more detailed guidance on the update cycles for the "IP Strategy."

This report does not reflect an official format of a DoD program's IP Strategy, nor are the steps intended to be completed in a particular order. The purpose is to suggest needed information and identify areas to investigate that will support the creation of an official version of the IP Strategy.

\subsection{Gather Program Information for Operational Context}

The Interim DoDI 5000.02 references the need for the IP Strategy to identify and manage the full spectrum of IP [Interim DoDI 5000.02 2013]. Program information helps set the stage for understanding decisions, limitations, or restrictions that will influence decisions on license rights in IP. Foundational information could include

- mission need and program end goals

- transaction type and associated rights

- lifecycle phase

- early planning decisions and program strategies 


\subsubsection{Mission Need and Program End Goals}

Understanding the mission need, program end goals and lifecycle phase provides the context for a strategy for rights in IP. "The mission need is the consequence of a performance deficiency in current or projected capabilities or of a technological opportunity to establish new or improved capabilities” [AcqStrat 1999]. Program “end goals” are broad statements on how to address the deficiency. The ultimate decisions related to license rights in IP should be traceable back to the mission needs and end goals.

The end goals are not to be confused with "means goals," which define paths or methods to achieve the end goals. Principal adjectives used to monitor the progress of "means goals" are specific, measurable, actionable, realistic, and time-bound (S.M.A.R.T.) [Pavlina 2005]. Understanding the mission need and goals leads to identification of necessary operational capabilities and information sources on deliverables and needed license rights.

\subsubsection{Transaction Vehicle and Associated Rights}

A transaction vehicle is the type of agreement used to obtain the end items of the program. Each vehicle has implications for rights in IP, so they are important to understand as a first step. There are several types of vehicles or agreements used by the DoD to obtain end items. The vehicles and governing laws provide specific rules for products and the resulting intellectual property.

For example, Public Law (P.L.) 96-517, known also as the Bayh-Dole Act and codified in 35 U.S.C. § 200-212, has had particular impact on experimental, developmental, or research work funded in whole or in part by the DoD as procurement contracts, grants, and cooperative agreements. This legislation created a uniform patent policy among the many federal agencies that fund research, enabling businesses and nonprofit organizations, including universities, to retain title to inventions made under federally funded research programs [Somers 2003].

In most cases, it provides for recipient ownership of inventions and government-purpose license rights for the federal government. It initially gave U.S. universities, small businesses, and nonprofits intellectual property control of their inventions and other intellectual property that resulted from government funding [Bayh-Dole 2014]. By Executive Orders 12591 and 12618, coverage was extended to contractors that are not small business firms or nonprofit organizations. The tradeoff for the DoD is that it retains its nonexclusive license to practice the "subject invention" throughout the world. A subject invention is an invention conceived or actually first reduced to practice under the contract. March-in rights give the $\mathrm{DoD}$ the right to take back the invention if it is not being effectively commercialized, but this right is almost never used [FedGrants 2014].

\subsubsection{Contract-Defense Federal Acquisition Regulation Supplement}

The DoD uses a procurement contract as the legal instrument to acquire (by purchase, lease, or barter) property or services for the direct benefit or use of the United States government. The FAR is the set of regulations governing all acquisitions and contracting procedures in the federal government. The DFARS (Defense Federal Acquisition Regulation Supplement) is an issuance of the Department of Defense and supplements the FAR. 
The Interim DoDI 5000.02 section on Generic and DoD-Specific Acquisition Program Models, Decision Points, and Phase Activities describes defense acquisition program models that illustrate combinations of deliverable components. The descriptions include a generic acquisition program structure, four defense acquisition program models, and two hybrid variations. These high-level descriptions included in the DODI 5000.02 are a first step in determining deliverables, and illustrate the combinations of items and components that could reside under a single program.

- Generic Product—could be a defense program or a commercial item or component

- Model 1: Hardware Intensive Program—A hardware intensive development program such as a major weapons platform.

- Model 2: Defense Unique Software Intensive Program-A model that is dominated by the need to develop a complex, usually defense-unique, software program that will not be deployed until several software builds have been completed.

- Model 3: Incrementally Fielded Software Intensive Program-A model that has been adopted for many database systems and upgrades to some command and control systems or weapons systems software. Fielding will likely occur in multiple increments in one- to two-year cycles.

- Model 4: Accelerated Acquisition Program-A model that applies when schedule considerations are dominant over cost and technical risk considerations; includes compressed or eliminated process phases and accepts potential inefficiencies to achieve deployment on a compressed schedule.

- Hybrid Model "A"-Software development should be organized into a series of testable software builds that lead up to the full capability needed to satisfy program requirements.

- Hybrid Model "B"-Includes a mix of incrementally fielded software item or component or releases that include intermediate software builds. All of the comments about incremental software fielding associated with Model 3 apply here as well [Interim DoDI 5000.02 2013].

\subsubsection{Cooperative Research and Development Agreement (CRADA)}

A Cooperative Research and Development Agreement (CRADA) is a written agreement between one or more federal laboratories, such as those operated by the DoD, and one or more nonfederal parties under which the DoD, through its laboratories, provides personnel, facilities, equipment or other resources with or without reimbursement (but not funds to nonfederal parties). The nonfederal parties provide personnel, funds, services, facilities, equipment, or other resources to conduct specific research or development efforts that are consistent with the mission of the laboratory. The statute specifies a basic patent clause concerning rights in future inventions granted to the DoD by the CRADA awardee [ARL 2013].

Patent and intellectual property rights belong to the inventor. The DoD is granted a royalty-free license for partner inventions under the CRADA for governmental purposes. The partner may negotiate for exclusive licenses for government inventions [TARDEC 2014]. Bayh-Dole does not apply to CRADAs.

\subsubsection{Grants}

According to DoD and Grants.Gov: A Guide For DoD Staff, a grant is a legal instrument that is consistent with 31 U.S.C. § 6304 and "is used to enter into a relationship the principal purpose of 
which is to transfer a thing of value to the recipient to carry out a public purpose of support or stimulation authorized by a law of the United States, rather than to acquire property or services for the direct benefit or use of DoD” [DCMA 2008].

Using this type of transaction, the contractor may retain the entire right, title, and interest throughout the world to each subject invention subject to the provisions of this clause and 35 U.S.C. § 203. With respect to any subject invention in which the contractor retains title, 37 CFR § 401.14 states that the federal government shall have a nonexclusive, nontransferable, irrevocable, paid-up license to practice or have practiced for or on behalf of the United States the subject invention throughout the world. Bayh-Dole applies to grants.

\subsubsection{Other Transaction (OT) Authority}

An Other Transaction (OT) is a special vehicle for obtaining and/or advancing research and development (R\&D) or prototypes. An OT is not a contract, grant, or cooperative agreement, and there is no statutory or regulatory definition of "other transaction."

Only those agencies such as the DoD that have been provided OT authority may engage in other transactions. This vehicle is not covered by either the FAR or DFARS. Research or science and technology OTs cannot be procurement contracts [OTA 2011].

An OT for prototype applies to weapons or weapons systems proposed to be acquired or developed by the DoD. The 2001 “Other Transactions” (OT) Guide for Prototype Projects, Section C2.3.1.3, describes two major concerns that affect a strategy for rights in IP in this type of transaction:

1. "Insufficient intellectual property rights at this stage hinder the government's ability to adapt the developed technology for use outside the initial scope of the prototype project."

2. "Where the government overestimates the intellectual property rights it will need, the government might pay for unused rights and dissuade new business units from entering into an Agreement” [OT Guide 2001].

"Other Transactions" do not come under the Federal Acquisition Regulation, its supplements (e.g. DFARS), or laws that are limited in applicability to procurement contracts. In general, rights in intellectual property for other transactions are consistent with the Bayh-Dole Act (37 U.S.C. Part 401 for subject inventions and patent rights and responsibilities and 10 U.S.C. § 2320-21 for technical data) [OT Guide 2001]. The Bayh-Dole Act (35 U.S.C. §201-204) requires that the government be granted a nonexclusive, nontransferable, irrevocable, paid-up license to practice or have practiced for or on behalf of the United States any subject invention throughout the world.

\subsubsection{Availability of Government-Furnished Licenses}

Program teams may overlook the possibility that another government organization may have already funded the development of items, components, or processes that an offeror is proposing to use or develop. If the government already has a license and the rights are at least government purpose rights (GPR), other government organizations may use that item or component under the same level of license. See DFARS 227.71 and DFARS 227.72 for discussions of government purpose rights. 


\subsubsection{Lifecycle Phase}

“The IP Strategy must be updated as appropriate to support and account for evolving IP considerations associated with the award and administration of all contracts throughout the system lifecycle," according to the Interim DoDI 5000.02. In addition to milestone updates, there may be several reasons for reviewing or recasting a strategy for rights in IP that could include

- $\quad$ kickoff of new development

- rework for phased competitions

- update for milestone or decision

- change in strategy

- change in requirements, design, or architecture

- changes to sustainment approach

- obsolescence or exit of supplier from market

New start development efforts have the most flexibility for acquiring needed deliverables and license rights in IP. Forward thinking on changes in requirements and technology, production, and/or logistics support ensures that the IP Strategy has the needed flexibility to meet these challenges. The Interim DoDI 5000.02 also cites the needs for updates of the program IP Strategy to

- ensure the ability to compete future sustainment efforts consistent with the Acquisition Strategy to include competition for spares and depot repair

- $\quad$ support and account for evolving IP considerations associated with the award and administration of all contracts throughout the system lifecycle [Interim DoDI 5000.02 2013]

\subsubsection{Existing Planning Decisions and Program Strategies}

Adoption of initiatives, choices, and policy implementation that will impact a strategy for rights in IP can occur at different points in a program lifecycle. In many cases, program decisions can occur well before the development of a strategy for rights in IP and can become the primary driver for framing rights. The PM and IP Strategy team must search for and reconcile, if needed, any firm commitments or plans that will impact the direction of a strategy for rights in IP.

Decisions made during early planning sessions can also move a strategy for rights in IP in specific directions for license rights in IP of program deliverable item(s). It is important to review and reconcile information across the System Requirements Document, Capability Based

Requirements document, Acquisition Strategy, Systems Engineering Plan, Lifecycle Sustainment Plan, Test and Evaluation Master Plan and any other pertinent materials that might have clues to needs. Program strategies can provide information that impacts the long-term operational context for rights in IP, such as

- key operational and sustainment requirements as described in documents related to capability needs

- acquisition strategies such as competitive award, sole source award, or multiple source development during each of the lifecycle phases 
- plans for systems engineering organization, staffing using organic, contractor, or mixed IPTs, and accessibility limits that are contractual requirements

- primary characteristics of sustainment implementation, contracting and supportability efforts

- $\quad$ any expected evolution of requirements and acquisition strategies across the lifecycle including the implementation of Open Systems Architecture, as appropriate [DoD AT\&L 2011]

Examples of early technical decisions with ramifications for a strategy for rights in IP include:

- competitive prototyping

- dual sourcing

- open systems architectures that enable competition for upgrades

- acquisition of complete technical data packages

- competition at the component level

- commercial software solution-predetermined selection of commercial software product strategy, which may be either proprietary or open source

- specific interoperability requirements across systems - strategies that will enable the system to interoperate with other U.S. and allied defense systems

- IT sustainment planning —infrastructure and direct deliverable support perspectives, particularly related to the source (current contractor, internal DoD, or competitive) of future efforts

- $\quad$ specific types of anti-tamper provisions to be employed to protect critical program information

- planning for alternative solutions and sources across the lifecycle

\subsection{Identify Deliverables Items and Components}

The Interim DoDI 5000.02 states that the IP Strategy will describe, at a minimum, "the program management assessment of program needs for deliverables” [Interim DoDI 5000.02 2013]. Deliverables could be tangible items, e.g., a tank, a missile, a computer software program, or a radar system. Likewise, deliverables could also include state-of-the-art technologies or capabilities, integration of components/subsystems from multiple vendors, incremental upgrades after initial program delivery, research efforts, or modest capability improvements to an existing item or component. Any of these items could be subject to IP protections.

Decomposition of the system along sustainable business and logical boundaries is not only an important step for managing a program, but also leads to a more precise definition of the documentation and license rights sought for each module. The object is to decompose the system being developed, modified, or upgraded, into defined modules and determine applicable license rights. Sizing a component is as much an art as technical prowess. This risk can be mitigated if a systems engineer is working with the program manager to understand the requirements, resources, and the government licenses available. 
This assessment of deliverable items and components must include all lifecycle phases in order to support both current needs and future strategy updates. These discussions will include items or components needed for operational test and evaluation, live fire test and evaluation, acceptance testing, installation, operation, maintenance, upgrade or modification, interoperability with other systems, disposal, and transfer of technologies to other programs, systems, and platforms. A strategy for rights in IP also should consider delivery of baseline documentation data, analysis data, cost data, test data, results of reviews, engineering data, drawings, models, and bills of materials.

Program managers need to engage in significant detective work among program management, systems engineering, support organizations, and logistics support to elicit needed rights. Common approaches for information gathering could include

- "gap" analysis-between minimum needs identified for the contemplated acquisition and licenses that the government already acquired under existing contracts. Careful review of the following can help determine what rights the government currently possesses:

- copies of relevant contracts

- FAR/DFARS standard clauses incorporated by reference into the contract

- copies of any asserted rights restrictions made by the contractor prior to an award in its completed DFARS § 252.227-7017 certification/representation

- copies of CDRLs delivered under predecessor contracts that would include restrictive markings

- review of information gathered from other strategies - analyzing other strategy documents to understand decisions that impact a strategy for rights in IP, such as the Acquisition Strategy and the Capabilities Development Document

- research into what license rights that the government already holds

- document analysis - gathering and reviewing all existing documentation from similar projects that is pertinent to objectives, data, or solutions that might be considered

- group techniques, include focus groups, brainstorming, use case development, individual interviews, and requirements workshops

- observation-observation and/or questions related to how the user works

- survey/questionnaire - data gathering from a large group of participants

- market research—can support how requirements may be logically broken out into segments to maximize competition

- records that substantiate sources of funding used to develop the item, component, or process delivered via those Contract Data Requirements Lists (CDRLs)

A common goal of these methods is to understand why the requirements community needs certain deliverables and what protections may be associated with them. The deliverables may enable multiple areas, including reliability, maintainability, operational availability, supportability, logistics footprint, mobility, and total ownership cost. Requirements should include not only "asis" needs but also address potential changes to systems and subsystems in the different lifecycle phases. 
For technical data and software, a Data Requirements Review Board must be established to ensure that all data requirements and their associated tasks are reviewed by a cross-section of the functional elements providing support to the system and/or equipment. Normally, engineering, item or component assurance, safety, test and evaluation, acquisition, contracts, legal counsel, management, financial, training, logistics support, configuration management, and data user functions are represented on the board, as required. More detail on this process and its requirements is available in DoD 5010.12-M-Procedures for Acquisition and Management of Technical Data.

\subsection{Identify IP Protections and Available Rights of Deliverables}

The government may own the delivered physical medium (deliverables) in/on which the embodiment of the intellectual property resides, but it will seldom take or receive ownership of the intellectual property protection (e.g. the patent or copyright) for which it receives a license.

It can be a major challenge for program managers and acquisition teams to obtain sufficient information on deliverables and associated categories of IP protection. In addition to the multiple rights associated with each category of intellectual property, it is very likely that a product may have multiple components. Each of those components could also be subject to one or more types of protection. For example, items such as a software system or application could have patent protection, copyright protection, and contain trade secrets. It is possible that

- A deliverable may be patented or patentable, eligible for a copyright or trademark protection, or qualify as a trade secret.

- A deliverable may be protected by a copyright and contain trade secrets.

- A deliverable may not qualify for protection under intellectual property law.

- A deliverable may have one or more components that include protection for more than one patent, copyright, or trade secret.

Different categories of intellectual property, transactions, and program needs result in different rights. Table 1 offers a quick review of the discussion in Section 3 of this report that lists rights by IP category that licensors/owners have.

Table 1: IP Categories and Owner Rights

\begin{tabular}{|c|c|}
\hline $\begin{array}{l}\text { Category of IP } \\
\text { Protection }\end{array}$ & Owner Rights \\
\hline Patent & $\begin{array}{l}\text { 1. Exclude others from making the invention } \\
\text { 2. Exclude others from using the invention } \\
\text { 3. "Exclude others from offering for sale, or selling the invention throughout the } \\
\text { United States or importing the invention into the United States" [USPTO } \\
\text { 2014] }\end{array}$ \\
\hline
\end{tabular}




\begin{tabular}{|c|c|}
\hline $\begin{array}{l}\text { Category of IP } \\
\text { Protection }\end{array}$ & Owner Rights \\
\hline Copyright & $\begin{array}{l}\text { 1. Reproduce the work in copies or phonorecords } \\
\text { 2. Prepare derivative works based upon the work } \\
\text { 3. Distribute copies or phonorecords of the work to the public by sale or other } \\
\text { 4. Transfer of ownership, or by rental, lease, or lending } \\
\text { 5. Perform the work publicly, in the case of literary, musical, dramatic, and } \\
\text { choreographic works, pantomimes, and motion pictures and other } \\
\text { audiovisual works } \\
\text { 6. Display the work publicly, in the case of literary, musical, dramatic, and } \\
\text { choreographic works, pantomimes, and pictorial, graphic, or sculptural works, } \\
\text { including the individual images of a motion picture or other audiovisual work } \\
\text { 7. Perform the work publicly (in the case of sound recordings) by means of a } \\
\text { digital audio transmission. [Copyright Office 2012] }\end{array}$ \\
\hline Trademark & $\begin{array}{l}\text { 1. Use } \\
\text { 2. Allow others to use }\end{array}$ \\
\hline Trade Secret & $\begin{array}{l}\text { 1. Copy the trade secret } \\
\text { 2. Use the trade secret } \\
\text { 3. Benefit from the trade secret } \\
\text { 4. Disclose the trade secret }\end{array}$ \\
\hline
\end{tabular}

To illustrate multiple IP protections for components of a single IT system, Jorda refers to work by Dr. Jay Dratler [Jorda 2007]. In Intellectual Property Law: Commercial, Creative, and Industrial Property, Dratler characterizes the complicated nature of identifying and understanding rights of a single IT system with a list of components and the IP categories that could be involved in a single IT system.

- patented hardware and software

- patented computer architecture on circuit designs

- trade-secret production processes

- copyrighted microcode

- copyrighted operating system

- copyrighted instruction manual

- $\quad$ semiconductor chips protected as mask works

- consoles or keyboards protected by design patents, or as trade dress under trademark principles

- trademark registration

"Even these examples are somewhat limited, because trade secrets can protect not only know-how and processes, but also large amounts of collateral data, information, and other know-how that are not found in patent specifications,” Jorda notes [Jorda 2007].

\subsection{Select Specific Rights in IP for Deliverables}

The Interim DoDI 5000.02 states that the IP Strategy will describe, at a minimum, "the program management assessment of program needs for Government rights to that IP." Government rights 
in IP are license rights in IP that the government obtains to make, buy, or sell items protected by patents; use, modify, reproduce, perform, or display items protected by copyright; and release or disclose protected trade secrets. [DFARS 2014].

It should be noted that the DoD obtains unlimited rights automatically in certain types of technical data. Included in this category are: computer software documentation, form, fit and function data, and data necessary for operations, maintenance, installation, and training purposes. The unlimited rights are in effect regardless of who funded of the research and development of the noncommercial item to which the technical data relates.

As a prerequisite, the program manager and contracting officer must fully understand licensing terms, including specific rights and limitations, if any, proposed by the offeror. With information on deliverables and rights in IP that could be acquired, the team can select the rights profile that best support needed capabilities. The following steps can help to document evolving rights strategies and selections:

1. Articulate DoD agency expectations that cover the whole lifecycle for the program, such as fulltime availability of the end item.

2. Construct high-level strategy statements that describe the agency's plan to meet expectations, such as " $24 \times 7$ uptime in operations" or "availability during the life of the end item regardless of force location in the world."

3. Identify and prioritize the necessary IP-related capabilities that the DoD agency must have to be successful with its plan, such as authority to engage competing contractor, if necessary, to perform work, including creating derivative works.

4. Select all license rights that support each decision driver (capability) and determine the best overall license option [Gross 2011].

The PM and team should also work within their program executive offices and across communities of interest to consider lifecycle needs for government access to and use of intellectual property. In addition to subject matter experts in design, development, deployment, sustainment, and disposal needs, the elicitation effort should also include sources that can speak to legal standards and contractual approaches.

Some critical questions to discuss for rights requirements include:

- What type of funding will be used and what types of licenses are available to the DoD?

- Which specific persons or entities who are not government employees will need to use those critical deliverable items or components?

- Which specific purposes (e.g., emergency repair, depot level maintenance, follow-on competitive acquisitions) will the item or component be used for?

- Which desired operational attributes have high priorities and would require specific rights such as access by competitors? Examples include

- reliability (ability to perform with correct, consistent results, e.g., mean time between failure for equipment)

- maintainability (easily serviced, repaired, or corrected)

- availability (accessed and operated when needed) 
- flexibility (easily adapted to changing requirements)

- $\quad$ portability of software (easily modified for a new environment)

- reusability (used in multiple applications)

- testability (easily and thoroughly tested)

- $\quad$ usability (easily learned and used), and other attributes [MIL-HDBK-520 2010]

The results of this analysis should guide the program in determining the specific license rights in IP that it will ask the contractor to furnish. For example, standard software license rights are unlimited, government purpose, and restricted. If the program requires other license rights, specifically negotiated rights can be considered. Documenting discussions and rationale ensures traceability between deliverable requirements and license rights selections. Requirements should include both upfront needs and potential changes to items and components in the different lifecycle phases.

\subsection{Framing a Strategy for Rights in IP}

The results of each of the previous sections provide foundational information to support a strategy for IP. Interim DoDI 5000.02 provides a high level description of the minimum elements to be included in a consistent IP Strategy. These elements "integrate technical requirements with contracting mechanisms and legal considerations to support continuous availability of multiple competitive alternatives throughout the product life cycle” [Interim DoDI 5000.02]. Minimum elements in the IP Strategy are:

- results of assessment by management of program needs for deliverables and associated rights in IP

- plans for competitive acquisition, whenever possible

- IP deliverables and associated rights for competitive and affordable acquisition and sustainment over the entire product lifecycle

- IP planning elements required by subpart 207.106 (S-70) of the Defense Federal Acquisition Regulation Supplement for major weapon systems and subsystems thereof

- evaluation and implementation of open systems architectures, where cost effective [Interim DoDI 5000.02 2013]

\subsubsection{Needs Assessment Results for Deliverables and Associated Rights in IP}

Thoughtful approaches to software system modularity, design documentation, and license rights entitlement will maximize a program's ability to utilize competitive alternatives for DoD development, modification, or upgrade effort. One suggestion is to consider a priced contract option for the future delivery of intellectual property rights not acquired upon initial contract award; and also consider the contractor's responsibility to verify any assertion of restricted use and release of data [USAF 2014].

"A key enabler for open architecture is the adoption of an open business model, which requires doing business transparently to leverage the collaborative innovation of numerous participants across the enterprise permitting shared risk, maximize asset reuse, and reduce total ownership costs” [OSA 2013]. An open business model requires doing business in a transparent way that 
utilizes the collaborative innovations of numerous participants across the enterprise. It can result in reduced total ownership costs, when effectively executed, by creating and maintaining competition from system "cradle to grave."

\subsubsection{Plans for Competitive Acquisition of Deliverables}

A competitive environment can be created and maintained through both direct and indirect means. The term "competitive rights" is a level of rights in data that is sufficient to enable full and open competitions when assuming that competent and eligible sources exist for such a competition. As previously mentioned in Section 4.3, some strategies to maximize competition include: competitive prototyping, dual sourcing, and open systems architecture that enable competition for upgrades, acquisition of technical data packages, and competition at the subsystem level [DoD BBP 2.0 2013].

Each of these strategies can have IP implications that must be part of a strategy for rights in IP.

\subsubsection{Competitive and Affordable Acquisition and Sustainment Across the Lifecycle}

According to the Open Systems Architecture Contract Guidebook for Program Managers, Version 1.1, May 2013, "the combination of open architecture and an open business model permits the acquisition of OSA that yields modular, interoperable systems allowing components to be added, modified, replaced, removed, and/or supported by different vendors throughout the life cycle in order to afford opportunities for enhanced competition and innovation.” An early, forward-thinking IP Strategy supports open architecture and the open business model. The program manager's responsibility is to plan for acquisition of necessary deliverables and associated license rights, tools, equipment, and facilities that support maintenance, and necessary organic depot maintenance capability that complies with statute and the Lifecycle Sustainment Plan [Interim DoDI 5000.02 2013].

\subsubsection{IP Planning Elements for DFARS Subpart 207.106 (S-70)}

DFARS Subpart 207.106 (S-70) (1) requires that acquisition plans for major weapon systems and subsystems of major weapon systems include

- assessment of the long-term technical data and computer software needs

- acquisition strategies for deliverables and associated license rights to support the lifecycle that may include development of maintenance capabilities within DoD or competition for sustainment contracts

- development of assessments and corresponding acquisition strategies that

- $\quad$ are developed before issuance of a solicitation

- $\quad$ address the merits of a priced contract option for the future delivery of data and associated license rights that were not initially acquired

- $\quad$ address the potential for sustainment plan changes over the lifecycle and

- $\quad$ apply to weapon systems and subsystems supported by performance-based logistics arrangements as well as by other sustainment approaches. 


\subsubsection{Evaluation/Implementation of OSA, Where Cost Effective}

"Program management is responsible for evaluating and implementing open systems architectures, where cost effective, and implementing a consistent IP Strategy. This approach integrates technical requirements with contracting mechanisms and legal considerations to support continuous availability of multiple competitive alternatives throughout the product life cycle" [Interim DoDI 5000.02 2013].

"Use of OSA standards and approaches allows for multiple vendors to propose innovative and affordable design solutions that will meet performance and interface requirements. The multiplicity of solution alternatives creates opportunity for competition for the system components without being locked into a single vendor's proprietary design or technology. This also facilitates fluid integration of new capability to meet warfighter demands" [DoD BBP June 2013].

The combination of an open technical architecture and early, forward-thinking IP Strategy in an open business model can yield modular, interoperable systems allowing components to be added, modified, replaced, removed, and/or supported by different vendors throughout their lifecycles [Interim DoDI 5000.02 2013]. Extensive detail on the DoD approach to OSA is available in the DoD Open Systems Architecture Contract Guidebook for Program Managers, v.1.1. 2013. 


\section{What Are IP Strategy Risks to Consider?}

Risk is the possibility or likelihood of harm, loss, or less-than-expected returns. The primary reason for risk identification and management is to assure that program decision-makers learn about and deal with important risks before they turn into issues [Alberts 2010]. There are several publications that explain how to create a risk management program. Among them are the Risk Management Guide for DoD Acquisition, Sixth Edition (Version 1.0), August, 2006 and Continuous Risk Management Guidebook, C. Alberts et al. Carnegie Mellon University. 1996.

This report will not provide extensive information on risk management, but a few basic points are helpful to start the discussion. In general, steps in risk management are

- assess continuously what could go wrong

- determine which risks are important to deal with

- implement strategies to deal with those risks

Risk control strategies include

- Acceptance. Risk severity is low enough that no action need be taken unless it occurs. If the risk occurs, the problem is fixable.

- Avoidance. The risk is no longer a possibility by design, removal, or other means.

- Mitigation. Work is done on unacceptable risks to reduce probability or their impact to a level below the maximum risk tolerance level.

- Transfer. The risk does not go away, but a person outside of the project is responsible.

Risks related to IP fall into multiple categories that can pose threats to program schedules, cost, and mission performance. Program managers and teams need to frame the facts of the risks and determine what actions might mitigate or lessen their impacts. The objective of this section is to generate discussion by the PM and team about managing risks related to the rights in IP and the Strategy. The following examples are not all of the risks that could exist, but serve to the breadth of risks that could become issues.

\subsection{Weak or Missing Rationale for the Selected IP Strategy}

If the sole rationale of a strategy for rights in IP is that the program will get the most license rights that exist in everything, the program is in trouble. The outcome of the process in Section 4, i.e., a strategy for rights in IP, should encompass the end goals, the needs for performance, cost, and schedule, and deliverables, and the available license rights to those deliverables. Preferences in these areas generally skew toward the most flexibility and the least risk of the of the positivenegative spectrum. However, definitions of "most flexibility" and "least risk" change as new technologies and approaches evolve. A current example of a more flexible and less risky preference is open competition over sole source. Examples of strategy statements that meet the preferred criteria are shown in Table 2 [U.S. Navy 2001]. 
Table 2: Notional Rationales for Parts of an IP Strategy

Commercial and non-development items reduce performance, schedule and cost risks by yielding more predicted functionality, producibility, and reliability. That is, the known unknowns and unknown unknowns have been reduced through iterative design, development and use. In other words, fewer surprises can be expected.

Open competition with multiple sources for system acquisition allows for the consideration of the largest number of possible solutions as well as the most dependable source given the technical and support strategies.

Commercial support and sustainment should reduce cost and lead time for support because the design/development and production contractor has developed the know-how, technical data, and sources for the system being supported and additional value chain links with their related cost and time do not have to be added [U.S. Navy 2001].

\subsection{Lack of Planning for Delivery Management}

DFARS 227.7203-1(b) requires that solicitations and contracts shall specify software and documentation to be delivered; separate contract line items, to the extent practicable, that are priced separately for each deliverable data item; a delivery schedule; methods for determining acceptability of deliverables, and agreed-upon arrangements for support, updates, and maintenance throughout the lifecycle. Planning "what and how" for these activities in advance is an effective approach to mitigating the risk of late discovery that the program is not receiving what it expected to receive. The DFARS section provides more detail for each of these delivery management activities. In addition, there are commercial and free tools available to develop and track CDRL submissions.

\subsection{Lack of Planning for Future Management}

An item that is under IP protection can be in service for decades. Two major risks that arise from a long lifecycle are cost and obsolescence. A strategy that locks in the source of the deliverable for the life of the product may be subject to significantly increased cost up to and through sustainment. Likewise, if the source of the deliverable goes out of business, the deliverable may require a replacement that may mean more time, more money, and possibly redesign. If the deliverable is or houses a technical product that becomes obsolete, replacement could be costly and/or impossible. It may take many man hours to keep the obsolete parts or products in operation. Mitigations to consider can include:

- evaluating technical solutions such as open systems architecture for long-term savings

- planning that supports late-life competitive procurement

- strategies such as code escrow to prevent loss of a software product if the vendor goes out of business

- performance-based logistics in the strategy to sustain performance of components throughout the product's lifecycle 


\subsection{Insufficient History of IP Ownership}

The government may be held liable to the patent owner for payment of the "reasonable and entire compensation" for its unauthorized use of the patent. Governmental use of a patented invention is viewed as an eminent domain taking of a license under the patent [28 U.S.C. § 1498]. The government may also delegate its eminent domain power over patents to contractors acting on its behalf. If a contractor working for the government infringes on a patent owned by someone else, that patent owner would sue the government (rather than the contractor) (FAR 52.227-1). A patent ownership history, particularly related to third-party owners, that identifies patents relevant to specific features supports appropriate considerations of indemnification, release protection, and licenses. Engagement of an IP attorney in the development process of a strategy for IP process is highly encouraged.

\subsection{Confusion Over of Rights in IP and Terms}

The terms "data rights," "technical data rights," and "computer software rights” are often misused. "Data rights" encompasses rights to both technical data and computer software. Technical data and its rights do not include (and specifically exclude) computer software and its rights. The license term for each of these types of data is available in DEFARS 227.71 and DFARS 227.72. The licenses of rights depend on the IP protection that the item falls under, the extent of government funding involved, nature of the data-whether it is a type of data in which the DoD automatically receives unlimited rights—and agency needs. Understanding DFARS 272.71, which describes technical data rights, and DFARS 272.72, which describes computer software rights, provide a good start in mitigating this risk. A program manager must ensure that items with restrictions are appropriately marked with legends, distribution statements, security classifications, and/or appropriate export control statements. These markings are the primary source of information about restrictions on the distribution and use of the data.

\subsection{Misunderstanding of Commercial Software Rights}

Due to the amount of commercial software in use by the government, it is also important to understand commercial software terms of use. Commercial software licenses offered to the government have the same terms as those offered to the public. However, DFARS 227.7202-1 Policy (a) states that "commercial computer software or commercial computer software documentation shall be acquired under the licenses customarily provided to the public unless such licenses are inconsistent with Federal procurement law or do not otherwise satisfy user needs."

Studies have shown that some terms normally included in a proprietary off-the-shelf (COTS) software product are inconsistent with federal government law. Provisions on liability, damages, attorneys' fees, choice of legal venue, or other matters may need additional negotiation.

Another major misunderstanding relates to the definition of commercial software. Both COTS software and open source software (OSS) fall into the commercial software category, but 
licensing terms of usage, available deliverables, derivative products, and resale are vastly different and require careful review. ${ }^{3}$

\subsection{Additional Thoughts to Consider}

These last questions come from a variety of sources. They may restate some previous suggestions in question form, lead to some other paths for further exploration, or generate new areas to pursue as you build your IP Strategy.

- Does the strategy for IP support the successful execution of the program across the entire period of performance?

- Has the program team performed a business case analysis to determine whether obtaining desired rights is the correct business decision?

- Has the program office included the contracting officer in discussions of the planned work effort?

- Was an IP attorney engaged in rights and IP review discussions?

- Are needed terms of agreements clearly understood that support needs for rights related to items under patent, copyright, trademark, and trade secret protection?

- Has the program team accounted for all deliverables, including commercial products, and data with unlimited rights, expired GPR rights, or expired Small Business Innovation Research (SBIR) rights?

- Are the key logistics criteria for reliability, maintainability, operational availability, and supportability covered the planned rights in IP?

- Does the strategy for IP reflect and coincide with other program office strategies, such as competitive procurement, additional quantities of the product, spare parts, or future upgrades/modifications, and/or a decision regarding performance of sustainment by either contractors or in-house contractors to perform sustainment of the product or bring support inhouse?

- Is there the capability to baseline all contents of a specific CDRL to a single level of license rights to the maximum extent practicable [USAF 2014]?

3 https://dap.dau.mil/acquipedia/Pages/ArticleDetails.aspx?aid=7bfcfeee-b24b-4fdd-ad7b-046437729519 


\section{Key Terms and Definitions}

Computer software - computer programs, source code, source code listings, object code listings, design details, algorithms, processes, flow charts, formulae, and related material that would enable the software to be reproduced, recreated, or recompiled. Computer software does not include computer databases or computer software documentation.

Computer software documentation - means owner's manuals, user's manuals, installation instructions, operating instructions, and other similar item or component, regardless of storage medium, that explain the capabilities of the computer software or provide instructions for using the software.

Copyright - an exclusive right to control the use, reuse, display, performance, or creation of "derivative works." Copyright is a form of protection provided by the laws of the United States (17 U. S. Code) to "original works of authorship.” This protection is available to both published and unpublished works. It applies to things such as literary works, pictorial, graphic or sculptural works, sound recordings, musical compositions, and architectural drawings, as well as "performance” art such as dances, choreography, and pantomimes. Common words, phrases, numbers and facts cannot be copyrighted.

Data - technical data or computer software, as defined in Federal Acquisition Regulation (FAR) Subpart 27.401-Definitions.

Data Rights - government's license rights in two major categories of intellectual property: (1) technical data, which includes any recorded information of a scientific or technical nature (e.g., item or component design or maintenance data, computer databases, drawings, and computer software documentation); and (2) computer software, which includes executable code, source code, code listings, design details, processes, flow charts, and related material.

Deliverable - a term used in project management to describe a tangible or intangible object to be delivered to DoD customer (either internal or external). It could be a report, a document, hardware or software component, or any other building block of an overall system.

Delivery - the formal act of transferring technical data, computer software, or computer software documentation to the DoD as expressly delineated in the contract (including, but not limited to the CDRL, the statement of work, or elsewhere in the contract), in accordance with a specified schedule.

Financial and/or Management Information - information that is not covered by the term "data" (technical data or computer software), but which is required by contract. It could include material such as integrated master schedules, design-to-cost/lifecycle cost and variance analysis reports, functional cost-hour reports, contract performance reports, contract fund status reports. 
Government's Rights in IP - license rights in IP obtained in whole or in part by the government so that it can use, modify, reproduce, release, perform, display, or disclose protected intellectual property (DFARS) or make, use, or sell inventions protected by a patent.

Intellectual Property - refers to creations of the mind, such as inventions; literary and artistic works; designs; and symbols, names, and images used in commerce.

Intellectual Property Protections - certain exclusive rights granted to owners of intellectual property to control the use and dissemination of their item or component. There are four ways to protect intellectual property—patent, trademark, copyright, and trade secret agreements and secrecy.

Lifecycle - total phases through which an item passes from the time it is initially developed until the time it is either consumed in use or disposed of as being excess to all known materiel requirements.

Patent - a legal monopoly over a unique, non-obvious process, mechanical device, article of manufacture, or composition of matter. In the U.S., patents are issued by the U.S. Patent and Trademark Office (USPTO), within the Department of Commerce, and are generally enforceable from date of issuance through 20 years from the filing date. Like any other property right, it may be sold, licensed, mortgaged, assigned or transferred, given away, or simply abandoned.

Requirement - an established need justifying the timely allocation of resources to achieve a capability and accomplish approved military objectives, missions, or tasks; also constraints, demands, necessities, needs, or parameters that must be met or satisfied, usually within a certain timeframe.

Technical Data - recorded information, regardless of the form or method of the recording, of a scientific or technical nature (including computer software documentation). The term does not include computer software or data incidental to contract administration, such as financial and/or management information.

Trade Secret - information, including a formula, pattern, compilation, program device, method, technique, or process, that: (1) derives independent economic value, actual or potential, from not being generally known to, and not being readily ascertainable by proper means by, other persons who can obtain economic value from its disclosure or use, and (2) is the subject of efforts (usually physical security and disclosure agreements) that are reasonable under the circumstances to maintain its secrecy. Examples include contractor technical drawings and computer software, customer lists, company financial information, cost and pricing data, contract bid information, algorithms, source code, and item or component recipes.

Trademark - includes any word, name, symbol, or device, or any combination thereof that is (1) used by a person, or (2) which a person has a bona fide intention to use in commerce. The symbol ( ${ }^{\circledR}$ identifies a trademark registered with the federal government. The symbol ${ }^{\text {тм }}$ identifies a federally unregistered trademark; and SM identifies an unregistered service mark. Trade and service marks are also protected under state and common law; and are identified by ${ }^{\mathrm{TM}}$ and SM. 


\section{References}

URLs are valid as of the publication date of this document.

\section{[AcqStrat 1999]}

Defense Systems Management College Acquisition Strategy Guide, Fourth Edition. Defense

Systems Management College Press. December 1999.

\section{[ARL 2013]}

United States Army Research Laboratory. Cooperative R\&D Agreements. 2013.

http://www.arl.army.mil/www/default.cfm?page=14

\section{[Bayh-Dole 2014]}

The Bayh-Dole Act Research \& History Central IP Mall, 2014. All rights reserved.

http://www.bayhdolecentral.com/

\section{[Cavicchi 2007]}

Cavicchi, Jon. What the LESI Guide to Licensing Best Practices Has To Say on Hybrid Patent and Trade Secret Licenses. Franklin Pierce Law Center. 2007.

http://www.tradesecretsblog.info/2007/10/what_the_lesi_guide_to_licensi.html

\section{[Copyright Office 2005]}

U.S. Copyright Office. Works in Public Domain. 2005. http://www.copyright.gov/docs/domain.html

\section{[Copyright Office 2012]}

Library of Congress, U.S. Copyright Office. Copyright Basics. May 2012.

http://www.copyright.gov/circs/circ01.pdf

\section{[DCMA 2008]}

Defense Contract Management Agency (DCMA). DoD and Grants.Gov: A Guide for DoD Staff. 2008.

http://guidebook.dcma.mil/31/dod_grants_gov_guide.pdf

\section{[De Llano 2014]}

De Llano, Ron. Patent Infringement Information for Inventors. Patent-Infringement.org. 2014. http://patent-infringement.org/government-patent-infringement

\section{[DFARS 2014]}

Defense Federal Acquisition Regulation Supplement. Part 252-Solicitation Provisions and Contract Clauses. Feb 2014.

http://www.acq.osd.mil/dpap/dars/dfars/html/current/252227.htm 
[DoD AT\&L 2011]

Office of Undersecretary of Defense for Acquisition, Technology, and Logistics. Technology Development Strategy [or] Acquisition Strategy for [Program Name]: [Sample Outline]. April 2011. http://www.acq.osd.mil/se/docs/PDUSD-Approved-TDS_AS_Outline-04-20-2011.pdf

[DoD BBP 2.0 April 2013]

Undersecretary of Defense, Acquisition, Technology, and Logistics. Better Buying Power: Understanding and Leveraging Data Rights in DoD Acquisitions. April 2013. https://dap.dau.mil/policy/Lists/Policy\%20Documents/Attachments/3375/BBP\%202.0\%20Imple mentation\%20Directive\%2024\%20April\%202013.pdf

[DoD BBP 2.0 June 2013]

Open Systems Architecture/Data Rights Team. Department of Defense. Better Buying Power: Understanding and Leveraging Data Rights in DoD Acquisitions. June 2013.

\section{[Interim DoDI 5000.02 2013]}

Interim DoD Instruction 5000.02, Operation of the Defense Acquisition System. November 25, 2013.

\section{[Experts123 2014]}

Experts 123. What Rights Does the Owner of a Trade Secret Have? 2014.

http://www.experts123.com/q/what-rights-does-the-owner-of-a-trade-secret-have.html

\section{[FedGrants 2014]}

Atlantic Information Services Inc. A Guide to Managing Federal Grants for Colleges and Universities. 2014.

\section{[Fedmarket 2014]}

Fedmarket. Other Government Transactions. 2014.

http://www.fedmarket.com/contractors/Other-Government-Transactions

\section{[Gross 2011]}

Gross, Charlene. A Decision Framework for Selecting Licensing Rights for Noncommercial Computer Software in the DoD Environment (CMU/SEI-2011-TR-014). Software Engineering Institute, Carnegie Mellon University, 2011.

http://resources.sei.cmu.edu/library/asset-view.cfm?AssetID=9995.

\section{[Holloway 2014]}

Holloway, Colin. Trademark Owner's Responsibilities. Demand Media. 2014

http://info.legalzoom.com/trademark-owners-responsibilities-25406.html

\section{[INTA 2014]}

International Trademark Association (INTA). Fact Sheets, Assignments, Licenses and Valuation: Trademark Licensing. 2014.

http://www.inta.org/TrademarkBasics/FactSheets/Pages/TrademarkLicensing.aspx 


\section{[IT Law 2014]}

WIKIA. Intellectual Property. IT Law Wiki.

http://itlaw.wikia.com/wiki/Intellectual_property

\section{[Jorda 2007]}

Jorda, Karl F. Chapter 11.5, “Trade Secrets and Trade-Secret Licensing,” Intellectual Property Management in Health and Agricultural Innovation: A Handbook of Best Practices. p.1044. 2007-2012.

http://www.iphandbook.org/handbook/ch11/p05/

\section{[Kaprove 2012]}

Kaprove, Caitlin; McQuade, Paul F.; \& Stouck, Jerry. Court Reaffirms Broad Immunity for Patent Infringing Government Contractors - Only Recourse For Patent Holders Is To Sue Government. Greenberg Traurig, LLP. 2012.

http://www.natlawreview.com/article/court-reaffirms-broad-immunity-patent-infringinggovernment-contractors-only-recours

\section{[LII 2014]}

Legal Information Institute. Trademark Infringement. Cornell University Law School. 2014. http://www.law.cornell.edu/wex/trademark_infringement

\section{[MIL-HDBK-520 2010]}

Department of Defense Handbook: Systems Requirements Document Guidance. Mil-HDBK-520 (USAF). March 5, 2010.

https://acc.dau.mil/adl/en-US/640084/file/69366/MIL-HDBK-520.pdf

\section{[OSA 2013]}

Undersecretary of Defense for Acquisition, Policy, and Logistics. DoD Open Systems

Architecture Contract Guidebook for Program Managers, v.1.1. 2013.

\section{[OT Guide 2001]}

Undersecretary of Defense for Acquisition, Policy, and Logistics. Other Transactions (OT) Guide for Prototype Projects. 2001.

\section{[OTA Guide 2010]}

Halchin, L. Elaine. Other Transaction (OT) Authority. Congressional Research Service. January 2010. http://research.policyarchive.org/19087.pdf

\section{[Pavlina 2005]}

Pavlina, Steve. End Goals vs. Means Goals. August 2005.

http://www.stevepavlina.com/blog/2005/08/end-goals-vs-means-goals/

\section{[Purvis 2002]}

Purvis, Sue A. The Fundamentals of Intellectual Property for the Entrepreneur. U.S. Patent and Trademark Office. 2002. 


\section{[Somers 2003]}

Somers, Jeffrey P. "Special Contractual and IP Rights Considerations: Sponsored Research Agreements, University and Government Licensing, Clinical Trial Agreements.” Journal of Biolaw and Business 6 (4). 2003.

\section{[TARDEC 2014]}

U.S. Army Tank Automotive Research Development and Engineering Center. Cooperative Research and Development Agreement - CRADA. 2014.

http://tardec.army.mil/business/crada.aspx

[17 U.S.C. § 202]

U.S. Code. Chapter 2. Copyright Ownership And Transfer.

\section{[U.S. Constitution Art. I, § 8, cl. 8.]}

The Constitution of the United States. Article 1, Section 8, Clause 8.

\section{[U.S. Navy 2001]}

U.S. Navy. Acquisition Strategy Decision Guide. January 2001.

http://www.navair.navy.mil/nawctsd/Resources/Library/Acqguide/asdgjan2001.pdf

\section{[USAF 2014]}

U.S. Air Force. Acquiring and Enforcing the Government's Rights in Technical Data and Computer Software Under Department of Defense Contracts: A Practical Handbook for Acquisition Professionals. March 2014.

https://acc.dau.mil/CommunityBrowser.aspx?id=431675

\section{[USDA 2014]}

U.S. Department of Agriculture. Proprietary Information and Trade Secrets. 2014.

http://www.dm.usda.gov/ocpm/Security\%20Guide/S2unclas/Propriet.htm

\section{[USPTO 2009]}

United States Patent and Trademark Office. Should I Register My Mark? 2009.

http://www.uspto.gov/trademarks/basics/register.jsp

\section{[USPTO 2011]}

United States Patent and Trademark Office. What Are Patents, Trademarks, Servicemarks, and Copyrights? General Information Concerning Patents. 2011.

http://www.uspto.gov/patents/resources/general_info_concerning_patents.jsp\#heading-2

\section{[USPTO 2014]}

United States Patent and Trademark Office. What is a Patent? Patents. 2014.

http://www.uspto.gov/patents/index.jsp\#

\section{[USPTO Trademark 2014]}

United States Patent and Trademark Office. Protecting Your Trademark: Enhancing Your Rights Through Federal Registration. 2014 http://www.uspto.gov/trademarks/basics/BasicFacts.pdf 


\section{[Warner-Lambert 1960]}

Warner-Lambert Pharmaceutical Co. v. John J. Reynolds, Inc., 178 F.Supp. 655 (S.D.N.Y. 1959), aff'd 280 F.2d 197 (2nd Cir. 1960).

\section{[WIPO 2014]}

WIPO - World Intellectual Property Organization (WIPO). What is Intellectual Property? 2014. http://www.wipo.int/about-ip/en/ 


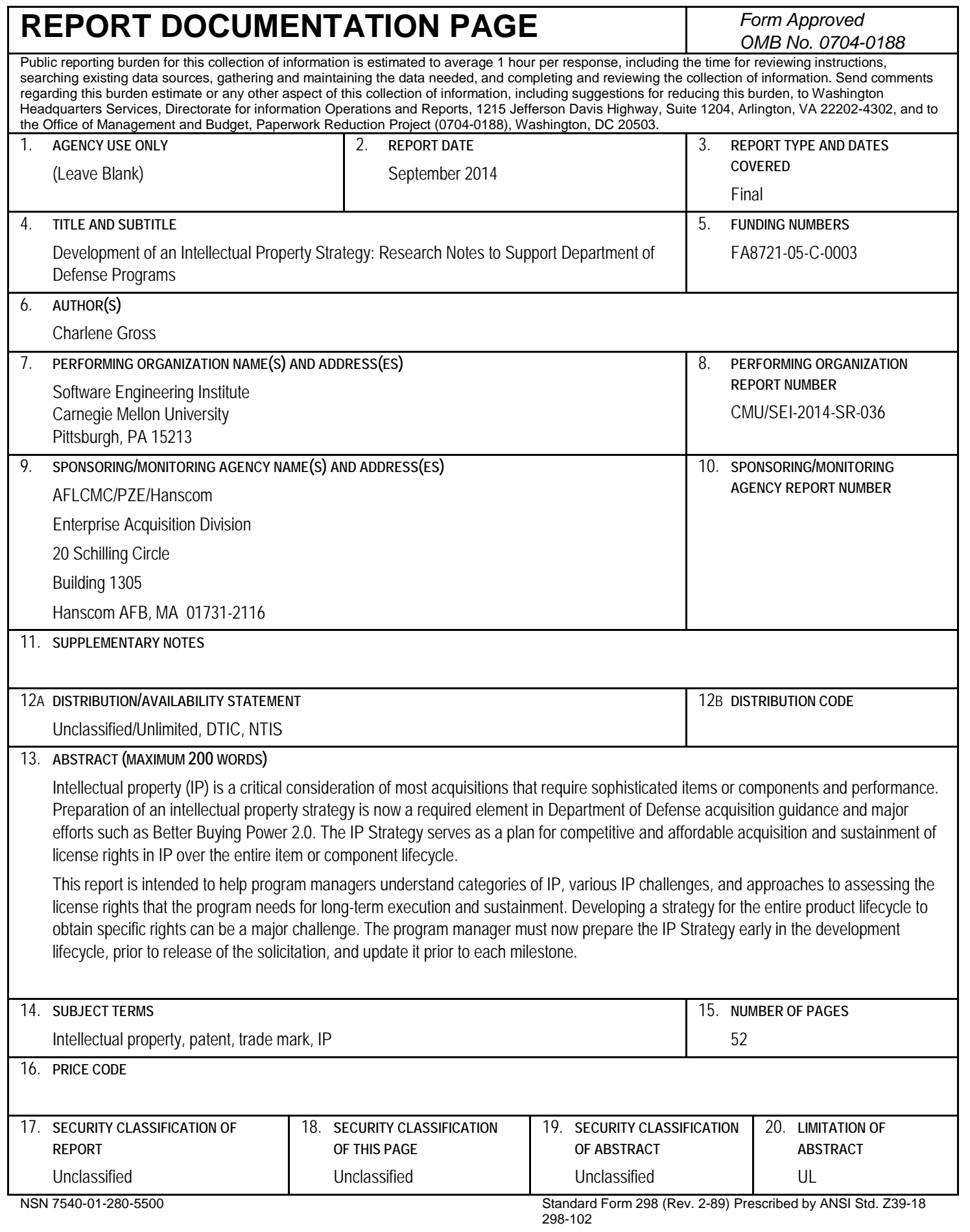

